\title{
MORPHOLOGICAL DIMORPHISM IN THE Y CHROMOSOME OF "PÉ-DURO" CATTLE IN THE BRAZILIAN STATE OF PIAUÍ*
}

\author{
Carmen M.C. Britto ${ }^{1}$ and Maria Luiza S. Mello ${ }^{2}$
}

\begin{abstract}
"Pé-duro" (hard foot) is a rare breed of beef cattle of European (Bos taurus taurus) origin, originated in northern and northeastern Brazil. Y chromosome morphology, outer genital elements and other phenotypic characteristics were examined in 75 "pé-duro" bulls from the Empresa Brasileira de Pesquisa Agropecuária (Embrapa) herd in the Brazilian State of Piauí. The purpose was to investigate possible racial contamination with Zebu animals (Bos taurus indicus) in a cattle that has been considered closest to its European origin (B. t. taurus). The presence of both submetacentric and acrocentric $Y$ chromosomes, typical of $B$. $t$. taurus and $B$. t. indicus, respectively, and the larger preputial sheath in bulls with an acrocentric $Y$ chromosome indicated racial contamination of the "pé-duro" herd with Zebu cattle. Phenotypic parameters involving horn, dewlap, ear, chamfer, and coat color characteristics, indicative of apparent racial contamination, were not associated with acrocentric $Y$ chromosome.
\end{abstract}

\section{INTRODUCTION}

"Pé-duro" is a breed of native Brazilian cattle derived from herds from the Iberian peninsula that were introduced into Brazil during the Portuguese colonization about the XVIth century. As they adapted to the new environment, the Iberian stock gradually gave rise to several varieties of locally adapted cattle known as crioulo, some of which are currently undergoing genetic "improvement" (Santiago, 1975; Camargo, 1990).

"Pé-duro" cattle originated in the northern and northeastern regions of Brazil, including the São Francisco valley from where the breed dispersed to the cerrados of the States of Minas Gerais and Goiás (Santiago, 1975). According to Athanassof (1958), "pé-duro" cattle arose from a Bos taurus ibericus stock, and the breed is currently classified as B. t. taurus.

This breed of cattle is very well adapted to the dry conditions of the northeastern Brazil. However, in the State of Piauí "pé-duro" cattle have almost become extinct because of indiscriminate slaughter, replacement with other breeds, especially Zebu, and crossbreeding, which has eliminated the typical characteristics of "pé-duro" animals (Carvalho, 1983, 1985).

The Empresa Brasileira de Pesquisa Agropecuária (Embrapa), with the support of the Centro Nacional de Recursos Genéticos (CENARGEN) and the Banco do Nordeste do Brasil, is engaged in an effort to preserve the germplasm of "pé-duro" bulls, and has created a

\footnotetext{
*Part of a thesis presented by C.M.C.B. to the Instituto de Biologia, Universidade Estadual de Campinas (UNICAMP), Campinas, SP, in partial fulfillment of the requirements for the Ph.D. degree.

${ }^{1}$ Departamento de Biologia, Universidade Federal do Piauí, 64000-000 Teresina, PI, Brasil.

${ }^{2}$ Departamento de Biologia Celular, Instituto de Biologia, UNICAMP, 13083-970 Campinas, SP, Brasil. Send correspondence to M.L.S.M.
}

nucleus of breeding stock of "pé-duro" cattle on the "Octávio Rodrigues" semi-arid experimental farm in the town of São João do Piauí, in southern Piauí. The main aim of this center is to preserve the germplasm of specimens, especially those of European origin. A description of these cattle is reported elsewhere (Britto, 1998).

The Y chromosome of bulls of European origin (Bos t. taurus) is submetacentric, while that of Afro-Asiatic Zebu bulls (Bos t. indicus) is acrocentric (Kieffer and Cartwright, 1968; Jorge, 1970, 1974; Gupta et al., 1974; Halnan, 1975; Tambasco, 1976; Benjamin and Bhat, 1977; Pinheiro et al., 1979a,b). In this study the Y chromosome morphology of "pé-duro" bulls of the Embrapa nucleus was examined, along with sex characteristics, in order to assess the level of racial contamination.

\section{MATERIAL AND METHODS}

Blood samples were obtained from 75 bulls belonging to the "Núcleo de Preservação do Gado Pé-duro" of Embrapa, Piauí. The ease with which the animals could be captured on the 6000-ha experimental station was the only selection criterion applied. Other criteria such as age and sexual maturity were not used.

The technique of Moorhead et al. (1960) was used for lymphocyte culture and chromosome analysis. Twenty-five metaphases from each animal were karyotyped with standard Giemsa staining. Biological parameters such as the size of the outer genital elements, and other phenotypic parameters such as horn, dewlap, ear, chamfer, and coat color characteristics, which could indicate racial contamination, were also analyzed.

\section{RESULTS}

All the animals examined had $2 n=60, X Y$ chromosomes. The autosomal pairs from 1-29 were all acro- 


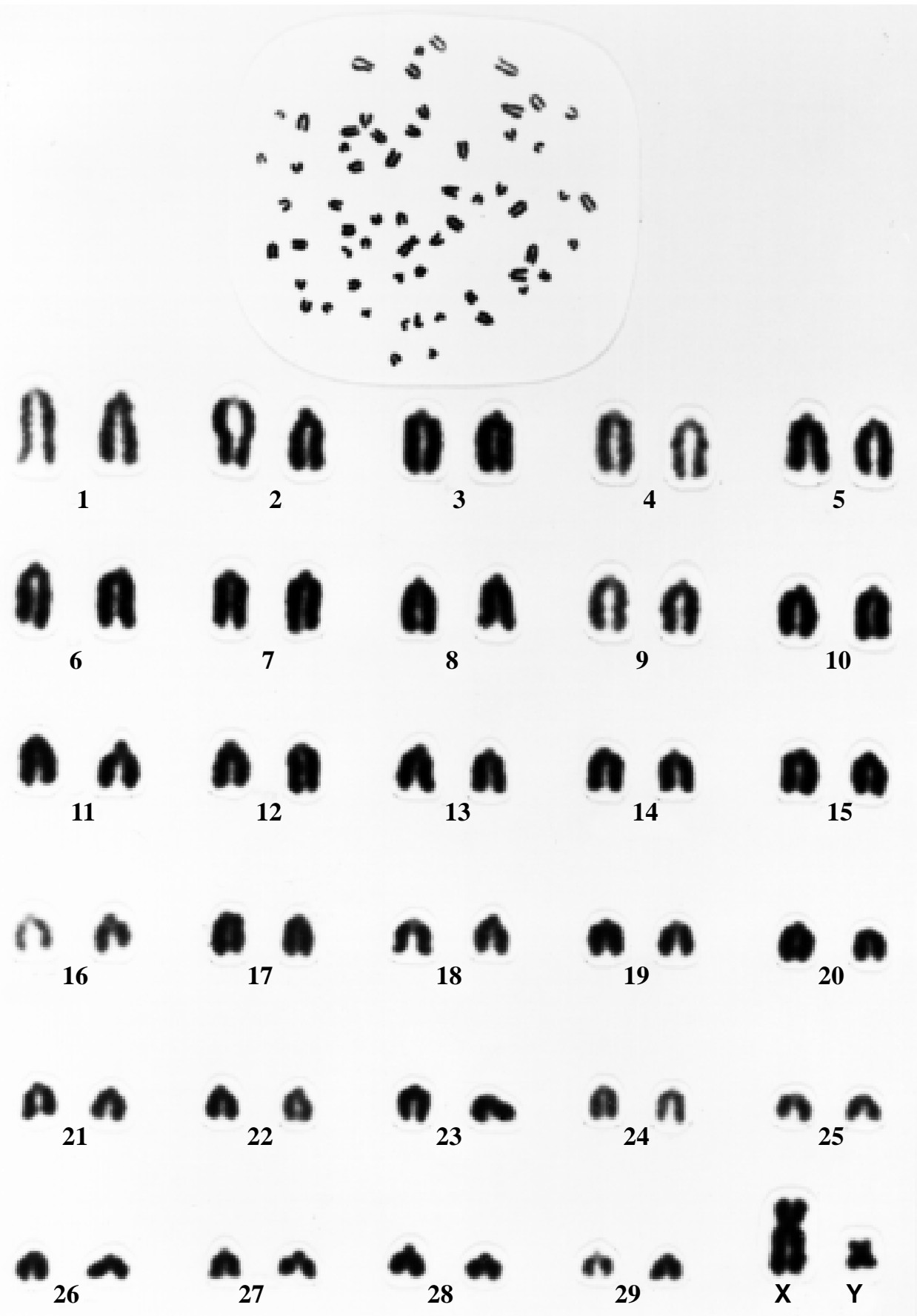

Figure 1 - Submetacentric Y chromosome-bearing karyotype of a "pé-duro" bull $(2 n=60, X Y)$.

centric and differed only in size. The $\mathrm{X}$ chromosome was metacentric (Figures 1 and 2).

Both submetacentric and acrocentric Y chromosome-containing karyotypes were detected (Figures 1 and 2). The frequency of the two $\mathrm{Y}$ chromosome types was nearly $1: 1$ in younger animals while the oldest bulls in the herd had mostly acrocentric Y chromosomes (Table I).

Since comparison of the measurements of the outer genital structures and other phenotypic characteristics showed no significant difference between age groups (data not shown), the age factor was disregarded in comparing the animals. The only significant difference in the structure of the outer genitalia was the larger prepuce size in acrocentric Y chromosome-bearing animals (Table II).

As regards the phenotypic characteristics considered to determine the apparent racial contamination of "péduro" bulls (Table III), short ears, arched horns and a reduced dewlap were suggestive of no racial contamination, whereas medium sized ears, open horns and a split dewlap were indicative of racial contamination. The chamfer color 


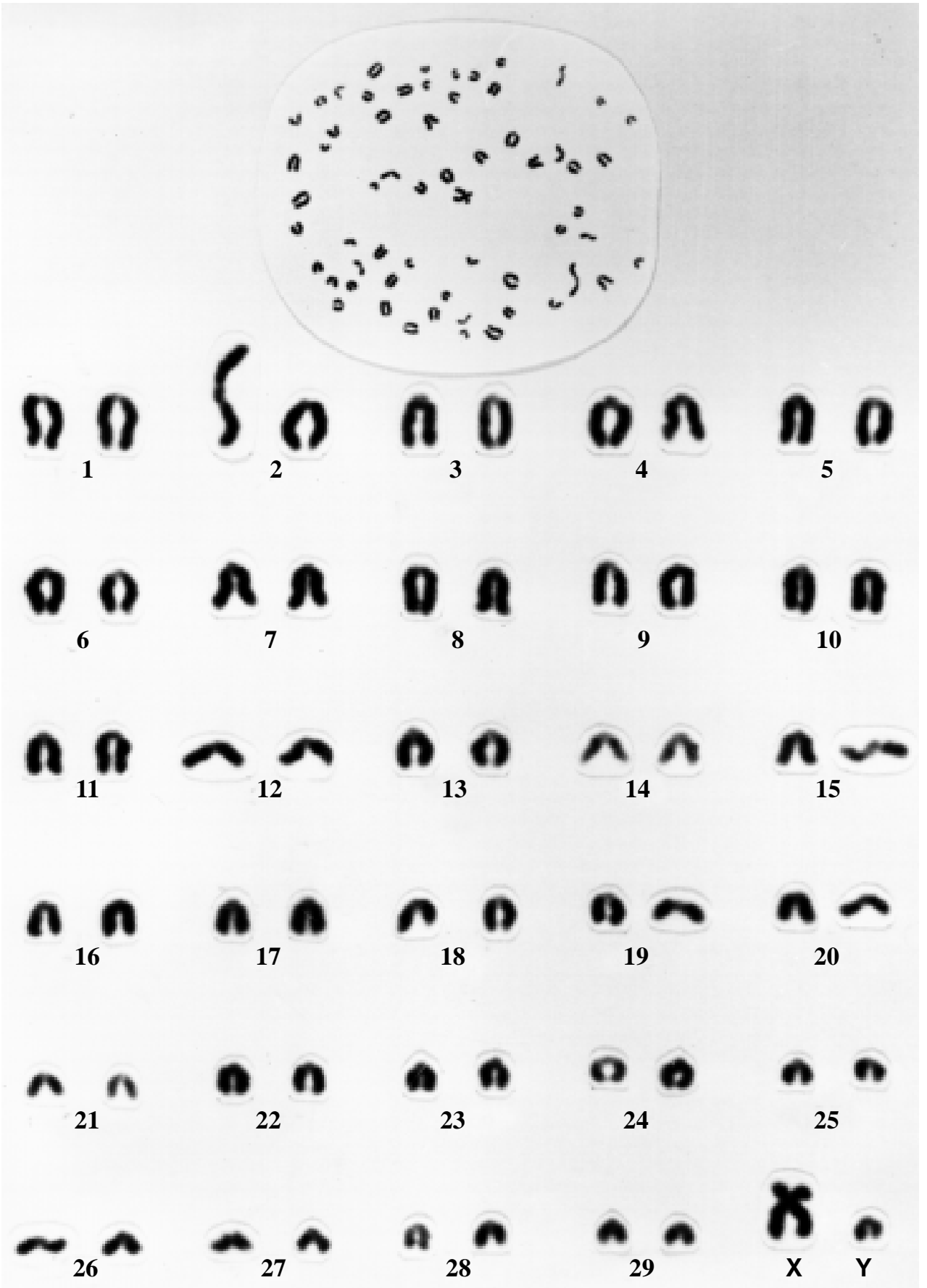

Figure 2 - Acrocentric Y chromosome-bearing karyotype of a "pé-duro" bull $(2 n=60, X Y)$.

Table I - Polymorphism in the Y chromosome morphology of "pé-duro" bulls.

\begin{tabular}{|c|c|c|c|}
\hline \multirow{2}{*}{$\begin{array}{l}\text { Y chromosome } \\
\text { type }\end{array}$} & \multicolumn{2}{|c|}{ Frequency of animals } & \multirow{2}{*}{$\begin{array}{l}\text { Total relative } \\
\text { frequency }(\%)\end{array}$} \\
\hline & I & II & \\
\hline Acrocentric & 21 & 30 & 68 \\
\hline Submetacentric & 17 & 7 & 32 \\
\hline
\end{tabular}

I, 12-36-month-old bulls. II, 37-96-month-old bulls. (light or dark) was not considered a good predictor of racial contamination, since it varies considerably (Carvalho, 1984). The level of racial contamination was considered low when the animals exhibited only one of the characteristics, and high when the animals exhibited two or more of these characteristics. $\chi^{2}$ analysis of the association between the degree of apparent racial contamination measured by the above characteristics and the $\mathrm{Y}$ chromosome type showed that these morphological variables were independent of Y chromosome type (Table IV). 
Table II - Morphometric data (in cm) for elements of the outer genitalia of "pé-duro" bulls with different Y chromosome types.

\begin{tabular}{|c|c|c|c|c|c|c|c|c|c|c|c|c|c|c|c|}
\hline \multirow[t]{3}{*}{ Y chromosome } & \multirow{3}{*}{$\begin{array}{c}\text { No. of } \\
\text { animals }\end{array}$} & \multicolumn{6}{|c|}{ Scrotum } & \multicolumn{4}{|c|}{ Testis width } & \multicolumn{4}{|c|}{ Prepuce } \\
\hline & & \multicolumn{2}{|c|}{ Length } & \multicolumn{2}{|c|}{ Perimeter } & \multicolumn{2}{|c|}{ Width } & \multicolumn{2}{|c|}{ Left } & \multicolumn{2}{|c|}{ Right } & \multicolumn{2}{|c|}{ Length } & \multicolumn{2}{|c|}{ Sheath length } \\
\hline & & $\mathrm{X}$ & S & $\mathrm{X}$ & S & $\mathrm{X}$ & S & $\mathrm{X}$ & $\mathrm{S}$ & $\mathrm{X}$ & S & $\mathrm{X}$ & S & $\mathrm{X}$ & S \\
\hline Acrocentric & 51 & 19.6 & 4.8 & 37.6 & 9.9 & 25.5 & 5.6 & 13.9 & 3.1 & 14.3 & 3.0 & 6.5 & 2.3 & 31.3 & 5.8 \\
\hline Submetacentric & 24 & 18.7 & 6.1 & 36.3 & 10.9 & 24.1 & 5.4 & 13.3 & 2.8 & 13.0 & 2.7 & 5.7 & 1.8 & 26.8 & 5.4 \\
\hline Student's $t$ & & & & & & & & & & & & & & & \\
\hline
\end{tabular}

*Significant difference $\left(\mathrm{t}_{0.05}=1.993\right) ; \mathrm{X}$, arithmetic mean; $\mathrm{S}$, standard deviation.

Table III - Phenotypic characteristics of 75 "pé-duro" bulls of Embrapa (Piauí).

\begin{tabular}{|llc|}
\hline \multicolumn{2}{l|}{ Characters } & Relative frequency (\%) \\
\hline \multirow{2}{*}{ Horns } & & \\
& Arched & 36.0 \\
& Open & 64.0 \\
& & \\
Ears & Reduced & 61.3 \\
& Split & 38.7 \\
& Short & 82.7 \\
Chamfer & Medium & 17.3 \\
& Light & 49.3 \\
& Dark & 50.7 \\
Coat color & Yellow & 41.3 \\
& Yellow and brown & 22.7 \\
& Brown & 14.7 \\
& Red & 9.3 \\
& White & 8.0 \\
& Black & 4.0 \\
\hline
\end{tabular}

\section{DISCUSSION}

The finding of both types of Y chromosomes indicates that the current "pé-duro" herd is heteromorphic. The acrocentric Y chromosome-bearing animals in the "pé-duro" herd were probably introduced through crossing with Zebu cattle. The submetacentric Y chromosome-bearing animals are closer to their European ancestry.

Racial contamination with Afro-Asiatic animals was also evident anatomically as there was a large preputial conformation, typical of B. t. indicus (Pinheiro et al., $1979 b$ ), in bulls with an acrocentric $Y$ chromosome. Genes in the respective $\mathrm{Y}$ chromosome type may have contributed to this sex characteristic. Dimorphism of the Y chromosome may also indicate the participation of both $B$. $t$. taurus and B. t. indicus in the formation of the "pé-duro" breed (Tambasco et al., 1985).

$B$. t. indicus which bears the acrocentric $\mathrm{Y}$ chromosome is considered to have evolved from B. t. taurus (Luz and Giannoni, 1978) and consequently specimens
Table IV - Y chromosome type versus the degree of apparent racial contamination (see text)

\begin{tabular}{|ccc|}
\hline $\begin{array}{l}\text { Apparent racial } \\
\text { contamination }\end{array}$ & \multicolumn{2}{c|}{ Y chromosome } \\
\cline { 2 - 3 } & Submetacentric & Acrocentric \\
\hline None & 8 & 13 \\
Observed (n) & 6.7 & 14.3 \\
Expected & 12 & 24 \\
Low $\quad 11.5$ & 24.5 \\
$\quad$ Observed (n) & 4 & 14 \\
Expected & 5.8 & 12.2 \\
High Observed (n) & & \\
Expected & & \\
$\mathrm{N}=75 ; \chi^{2}=1.18<\chi_{0.05}^{2}=5.99$. &
\end{tabular}

closely related to $B$. t. indicus specimens may still bear some phenotypic characteristics of their European ancestry.

The racial contamination of the "pé-duro" herd with Zebu breeds does not invalidate Embrapa's efforts to preserve the "pé-duro" breed from extinction. Other wellknown preserved breeds also show racial contamination, as is the case of American Longhorn cattle contaminated mainly with Hereford and Shorthorn breeds, and Hungarian Steppe Grey cattle contaminated with the Italian Maremma and Ukranian Grey breeds (Kidd et al., 1980; Bodó, 1984). Embrapa will now have to decide whether breed "decontamination" is desirable, in which case selecting for animals of predominantly European ancestry would be necessary.

\section{ACKNOWLEDGMENTS}

This study was supported by CAPES/PICD and CNPq. Publication supported by FAPESP.

\section{RESUMO}

Um plantel de touros "pé-duro", consistindo de 75 animais do núcleo da Embrapa envolvido com a preservação desse gado no Estado do Piauí, foi examinado quanto à morfologia do seu cromossomo Y, bem como em relação a elementos da genitália 
externa e outras características fenotípicas dos machos. O objetivo era investigar a contaminação racial por animais zebuínos (Bos taurus indicus) num gado bovino que tem sido considerado mais próximo de sua origem européia (Bos taurus taurus). Tanto a forma submetacêntrica quanto a forma acrocêntrica do cromossomo Y, típicas das sub-espécies B. t. taurus e B.t. indicus, respectivamente, bem como maior bainha prepucial nos espécimes portadores do cromossomo Y acrocêntrico, indicativa de contaminação racial por gado zebuíno, foram detectadas no rebanho "pé-duro" mantido no núcleo da Embrapa. Outras características fenotípicas analisadas que podem informar sobre a contaminação racial aparente não foram associadas ao tipo de cromossomo Y. A detecção de contaminação racial no estoque de touros "pé-duro" aqui analisado não invalida os esforços da Embrapa em preservar este gado de importância regional para o Nordeste do Brasil, porém quase extinto.

\section{REFERENCES}

Athanassof, N. (1958). Raças de gado comum sem aptidões especializadas. In: Manual do Criador de Bovinos. Melhoramentos, São Paulo, pp. 191-214.

Benjamin, B.R. and Bhat, P.N. (1977). Chromosomal studies on cattle with special reference to crossbreeding. Indian J. Anim. Sci. 47: 4-7.

Bodó, I. (1984). Maintenance of living herds of large farm animals. In: Manual for Training Courses on the Animal Genetic Resources Conservation and Management. Food and Agriculture Organization of the United Nations (FAO), Budapest, Vol. 2, pp. 37-47.

Britto, C.M.C. (1998). Citogenética do Gado Pé-duro. EDUFPI, Teresina.

Camargo, A.H.A. (1990). Ganado Criollo del Brasil: Origen y Características Zootecnicas. Boletin de Información sobre Recursos Genéticos Animales. FAO \& UNEP, Roma, pp. 11-16.

Carvalho, J.H. (1983). Gado Pé-duro: Esperança de Preservação. BNB Notícias, Fortaleza, 42: 4.

Carvalho, J.H. (1984). Relatório de Atividades do Núcleo de Preservação do Gado Pé-duro ou Curraleiro. EMBRAPA, Unidade de Execução de Pesquisa de Âmbito Estadual/UEPAE de Teresina.

Carvalho, J.H. (1985). Pé-duro, patrimônio preservado no Piauí. Dirigente Rural 24: 26-28.

Gupta, P., Singh, L. and Ray-Chaudhuri, S.P. (1974). Chromosomes of Indian breeds of cattle. Nucleus 17: 129-132.

Halnan, C.R.E. (1975). Chromosomes of cattle: present clinical status and promise. Vet. Rec. 96: 148-151.

Jorge, W. (1970). Cariologia comparada de algumas raças de B. taurus taurus (L.), B. taurus indicus (L.) e de seus cruzamentos. Master's thesis, UNESP, Botucatu.

Jorge, W. (1974). Chromosome study of some breeds of cattle. Caryologia 27: 325-329.

Kidd, K.K., Stone, W.H., Crimella, C., Carenzi, C., Casati, M. and Rognoni, G. (1980). Immunogenetic and population genetic analyses of Iberian cattle. Anim. Blood Groups Biochem. Genet. 11: 21-38.

Kieffer, N.M. and Cartwright, T.C. (1968). Sex chromosome polymorphism in domestic cattle. J. Hered. 59: 35-37.

Luz, M.R. and Giannoni, M.A. (1978). Estudo biométrico do cariótipo da sub-espécie Bos taurus indicus. Científica 6: 105-119.

Moorhead, P.S., Nowell, P.C., Mellmann, W.J., Battibs, D.M. and Hungeford, D.A. (1960). Chromosome preparations of leukocytes cultured from human peripheral blood. Expt. Cell Res. 20: 613-616.

Pinheiro, L.E.L., Ferrari, I. and Lobo, R.B. (1979a). Robertsonian translocation in imported bulls utilized at artificial insemination centers in Brazil. Rev. Bras. Genét. II: 135-143.

Pinheiro, L.E.L., Erdtman, B., Mattevi, M.S. and Mies Filho, A. (1979b). Análise citogenética em bovinos da raça Ibagé. Científica (Special No.): 29-32.

Santiago, A.A. (1975). Os Cruzamentos na Pecuária Bovina. Instituto de Zootecnia, São Paulo, pp. 254-255.

Tambasco, A.J. (1976). Contribuição ao estudo citogenético em bovinos normais e em bovinos com problemas de reprodução. Doctoral thesis, Faculdade de Medicina, USP, Ribeirão Preto.

Tambasco, A.J., Trovo, J.B.F. and Barbosa, P.F. (1985). Estudo cromossômico em raças naturalizadas de bovinos. 22a. Reunião Anual da Sociedade Brasileira de Zootecnia, Camboriú. Anais, p. 154.

(Received July 30, 1998) 
